\title{
Action of omeprazole (a benzimidazole derivative) on secretory responses to sham feeding and pentagastrin and upon serum gastrin and pancreatic polypeptide in duodenal ulcer patients
}

\author{
S J KONTUREK, N KWEICIEN', W OBTUKOWICZ, \\ B KOPP, AND J OLEKSY
}

From the Institute of Physiology, Medical Academy, Kraków, Poland

SUMmaRY The effects of omeprazole, a benzimidazole derivative, have been determined on the secretory responses to modified sham feeding and pentagastrin, and upon serum gastrin and pancreatic polypeptide concentrations in duodenal ulcer patients. Intragastric administration of omeprazole in doses of 2 and $6 \mu \mathrm{mol} / \mathrm{kg}$ produced, respectively, about $50 \%$ and $90 \%$ reduction in acid outputs in responses to modified sham feeding and pentagastrin without affecting serum gastrin and pancreatic polypeptide response to modified sham feeding.

Benzimidazole derivatives represent a new class of drugs which probably inhibit gastric $\mathrm{H}^{+}$secretion by suppressing the activity of $\mathrm{H}^{+} / \mathrm{K}^{+}$-ATPase, an enzyme playing a key role in the proton pump of the parietal cells. ${ }^{1-3}$

Previous studies in animals have shown that these agents are capable of inhibiting gastric $\mathrm{H}^{+}$secretion induced by a variety of stimulants both in vivo and in vitro. ${ }^{1-6}$ Olbe et at recently reported that one of the representatives of this group of agents (H149/94) reduces dose dependently pentagastrin induced $\mathrm{H}^{+}$ secretion in healthy volunteers, the reduction lasting over 36 hours after single oral dose of the drug.

This study was designed to determine the effects of omeprazole, a benzimidazole derivative, on modified sham feeding and pentagastrin stimulated acid and pepsin secretion, and serum gastrin and pancreatic polypeptide concentrations in duodenal ulcer patients.

\section{Methods}

\section{SUBJECTS}

Eight male patients (mean age 22 years, range 19-25 years; mean weight $70 \mathrm{~kg}$, range $67-78 \mathrm{~kg}$ ) with established chronic duodenal ulcer disease in clinical remission were repeatedly tested for this study. The

Address for correspondence: Prof dr S J Konturek, Institute of Physiology, 16 Grzegórzecka St, 31-531 Kraków, Poland.

Received for publication 28 March 1983 study was approved by a Human Research Review Committee and informed consent was obtained from each subject.

\section{SECRETORY PROCEDURE}

The tests were performed after an overnight fast and any antisecretory medication was withdrawn at least five days before the study.

A double lumen gastroduodenal tube was passed under fluoroscopic control for gastric juice collection as described previously. ${ }^{8}$ Residual gastric contents were discarded and the gastric aspirates were collected by a suction pump in 15 minute periods. The amounts of acid collected were determined by titration to $\mathrm{pH} 7.0$ using an automatic titrator (Autoburette, Radiometer, Copenhagen). Pepsin activity in the gastric juice was measured by a modification of the Anson ${ }^{9}$ haemoglobin method and pepsin outputs were expressed in milligrams of pepsin per 15 minutes.

After a 60 minute basal period, gastric aspiration was stopped and omeprazole or vehicle was administered intragastrically for 30 minutes. Omeprazole (AB Hässle, Sweden) was dissolved in $100 \mathrm{mM}$ solution of $\mathrm{NaHCO}_{3}$. In eight patients omeprazole was given in a dose of $2 \mu \mathrm{mol} / \mathrm{kg}(0.69 \mathrm{mg} / \mathrm{kg})$ and in four of them a dose of $6 \mu \mathrm{mol} / \mathrm{kg}(2.07 \mathrm{mg} / \mathrm{kg})$ was also administered. The drug was administered intragastrically via a nasogastric tube in the volume of $30 \mathrm{ml}$ of $\mathrm{NaHCO}_{3}$ solution. After omeprazole 
administration the aspiration was stopped for 30 minutes and restarted about 20 minutes before the beginning of the modified sham feeding or the pentagastrin infusion with an initial 5 minutes to remove residual gastric contents. Then aspiration of gastric content was restarted, the residual content was discarded and the collection of the gastric juice was continued for 15 minutes, before, 15 minute during, and 75 minutes after modified sham feeding. Finally, pentagastrin $(2 \mu \mathrm{g} / \mathrm{kg} / \mathrm{h})$ was infused intravenously for 75 minutes and the collection of gastric juice was prolonged for this period of time. In control tests, $30 \mathrm{ml}$ of $100 \mathrm{mM} \mathrm{NaHCO}$ placebo, without omeprazole, was introduced into the stomach for $\mathbf{4 5}$ minutes before the start of modified sham feeding or pentagastrin infusion.

During the modified sham feeding the subjects were served an appetising meal consisting of $250 \mathrm{~g}$ beef steak, $150 \mathrm{~g}$ fresh potatoes with about $250 \mathrm{ml}$ water to drink. The food was tasted, chewed, and spat out. All meals were prepared in a separate building so that the subject could not see or smell the food until the time of the modified sham feeding. The modified sham feeding procedure took 15 minutes and during this time gastric aspirate was carefully checked for swallowed food and none was found. In addition, phenol red was added to the 250 $\mathrm{ml}$ of water used in the modified sham feeding and gastric samples were analysed for phenol red and in six out of a total of 20 tests with modified sham feeding 4-9\% phenol red was found in the gastric aspirates. Phenol red concentration in each sample was measured spectrophotometrically at $575 \mu \mathrm{m}$ after being alkalinised to $\mathrm{pH} 11.5$.

The peak $\mathrm{H}^{+}$or pepsin outputs in response to modified sham feeding or pentagastrin was calculated from the highest two consecutive outputs recorded after modified sham feeding or pentagastrin stimulation.

\section{RADIOIMMUNOASSAY}

Venous blood samples were obtained from a peripheral vein every 30 minutes, once during basal gastric collection, once 15 minutes before the modified sham feeding, and at $15,30,60$, and 90 minutes thereafter. Serum gastrin and pancreatic polypeptide was measured in each sample as described previously. ${ }^{8}$

Statistical significance of difference was calculated using the Mann-Whitney $U$ test for unpaired data. ${ }^{10}$ All value are expressed as means \pm standard error of the mean.

\section{Results}

The time course of gastric $\mathrm{H}^{+}$secretion and serum gastrin concentrations before, during, or after the modified sham feeding with and without omeprazole in eight duodenal ulcer patients is shown in Fig. 1. In control tests, the mean $\mathrm{H}^{+}$output reached its peak in the second 15 minute period after the start of the modified sham feeding and was significantly raised above basal level for the following hour. The mean 15 minute peak $\mathrm{H}^{+}$output in response to the modified sham feeding reached about $60 \%$ of that in response to pentagastrin (Fig. 2).

Pepsin secretion in response to modified sham feeding increased mainly because of the rise in the volume of gastric juice and the peak output was not statistically different from that recorded in tests with pentagastrin stimulation (Fig. 3).

Omeprazole given intragastrically in a dose of $2 \mu \mathrm{mol} / \mathrm{kg}$ significantly reduced basal $\mathrm{H}^{+}$secretion and inhibited modified sham feeding-induced peak $\mathrm{H}^{+}$secretion by about $54 \%$. Pepsin outputs were reduced to smaller extent and mainly resulted from the diminution of the volume of the gastric juice (Fig. 2).

A dose of $2 \mu \mathrm{mol} / \mathrm{kg}$ omeprazole inhibited peak $\mathrm{H}^{+}$response to pentagastrin by about $50 \%$ and peak pepsin output to pentagastrin only by about $30 \%$
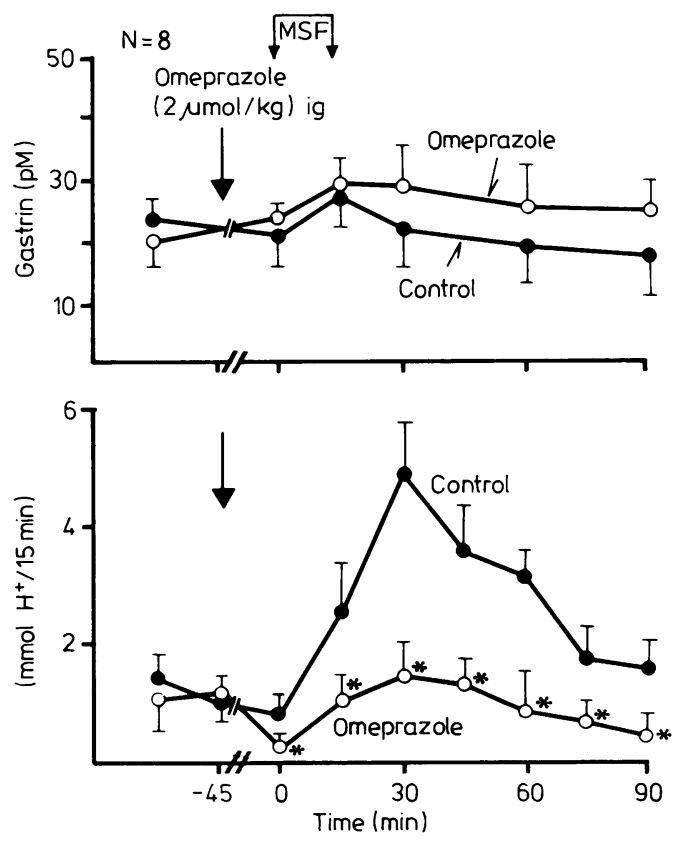

Fig. 1 Effect of omeprazole given orally in dose of $2 \mu \mathrm{mol} / \mathrm{kg}$ on serum gastrin concentrations and gastric acid response to the modified sham feeding in duodenal ulcer patients. Mean $\pm S E M$ of eight tests on eight patients.

* Significant $(p<0.05)$ decrease below control valve. 


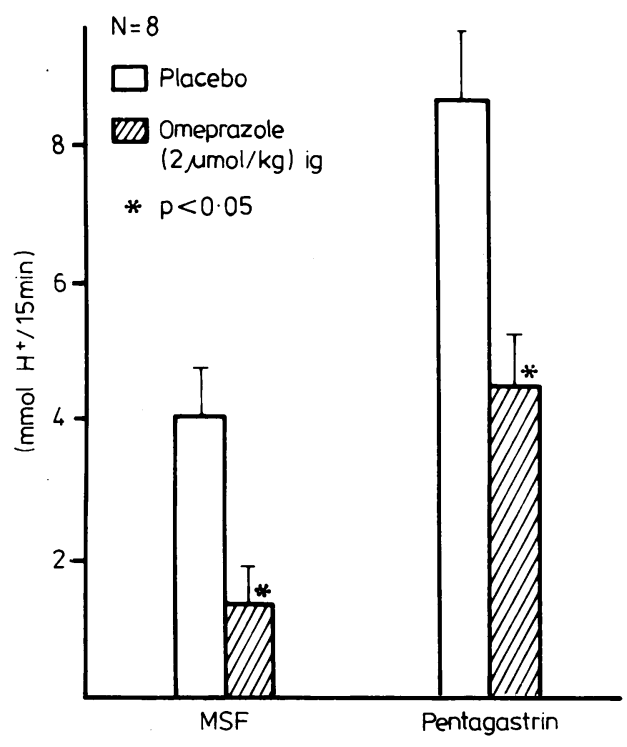

Fig. 2 Mean acid outputs in response to modified sham feeding and pentagastrin without (placebo) and with pretreatment with omeprazole. Mean \pm SEM of eight tests on eight duodenal ulcer patients. * Significant $(p<0.05)$ decrease below the control value obtained with placebo.

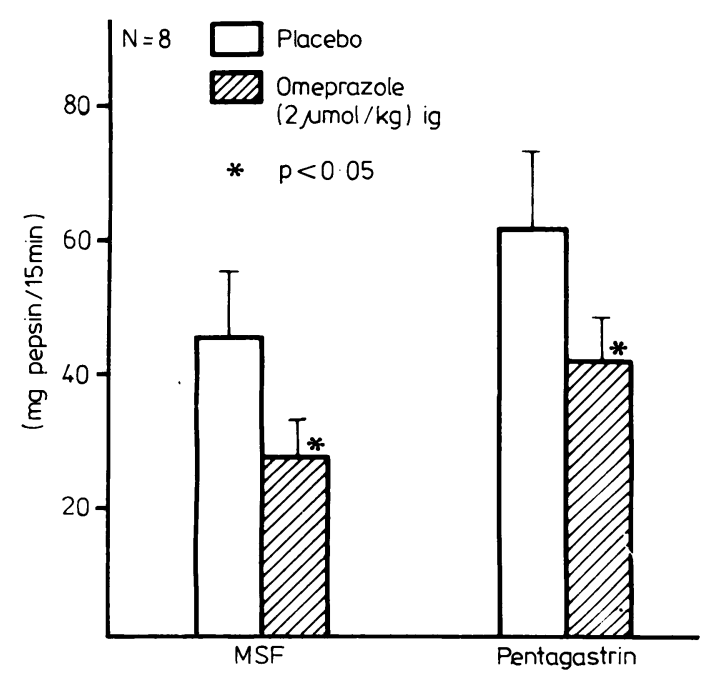

Fig. 3 Pepsin outputs in tests as on Fig. 2.
(Figs 2 and 3).

At a dose of $6 \mu \mathrm{mol} / \mathrm{kg}$, omeprazole caused almost complete suppression of modified sham feeding and pentagastrin induced acid and pepsin secretions (Table 1).

Modified sham feeding did not significantly affect serum gastrin concentrations and no significant alterations were seen after omeprazole administration (Fig. 1). Modified sham feeding caused a rapid increase in serum pancreatic polypeptide concentrations, usually reaching the peak in the first 15 minute period after the start of the modified sham feeding. Omeprazole failed to significantly affect basal or modified sham feeding-induced peak pancreatic polypeptide concentration (Table 2 ).

No symptoms or side effects were recorded with omeprazole. No change in blood pressure, pulse rate, or body temperature was noted during or after the administration of the drug.

\section{Discussion}

The results of present investigations have shown that intragastric administration of omeprazole in duodenal ulcer patients results in a dose dependent reduction in gastric acid and pepsin secretion in response to sham feeding or pentagastrin stimulation without affecting serum hormonal responses to this stimulation.

Table 1 Effects of omeprazole given intragastrically in doses of 2 and $6 \mu \mathrm{mol} / \mathrm{kg}$ on mean peak acid and pepsin secretions in tests with modified sham feeding and pentagastrin (mean $\pm S E M)$

\begin{tabular}{|c|c|c|c|}
\hline Type of test & $\begin{array}{l}\text { Patients } \\
\text { (no) }\end{array}$ & $\begin{array}{l}\text { Acid output } \\
(\mathrm{mmol} / 15 \mathrm{~min})\end{array}$ & $\begin{array}{l}\text { Pepsin output } \\
\text { (mg/15 min) }\end{array}$ \\
\hline $\begin{array}{l}\text { Modified sham feeding } \\
\text { alone (control) }\end{array}$ & 8 & $\begin{array}{l}4.920 \\
\pm 1.432\end{array}$ & $\begin{array}{l}52 \cdot 18 \\
\pm 12 \cdot 60\end{array}$ \\
\hline $\begin{array}{l}\text { Modified sham feeding } \\
\text { +omeprazole }\end{array}$ & & & \\
\hline $2 \mu \mathrm{mol} / \mathrm{kg}$ & 8 & $\begin{array}{l}2.275^{*}(54 \%) \\
\pm 0.234\end{array}$ & $\begin{array}{l}29 \cdot 08^{*}(44 \%) \\
\pm 6 \cdot 10\end{array}$ \\
\hline $6 \mu \mathrm{mol} / \mathrm{kg}$ & 4 & $\begin{array}{l}0 \cdot 310^{*}(94 \%) \\
\pm 0 \cdot 210\end{array}$ & $\begin{array}{l}16 \cdot 24^{*}(69 \%) \\
\pm 4 \cdot 16\end{array}$ \\
\hline $\begin{array}{l}\text { Pentagastrin alone } \\
\text { (control) }\end{array}$ & 8 & $\begin{array}{l}8.042 \\
\pm 1 \cdot 750\end{array}$ & $\begin{array}{l}54.79 \\
\pm 7 \cdot 60\end{array}$ \\
\hline $\begin{array}{l}\text { Pentagastrin } \\
\text { +omeprazole } \\
2 \mu \mathrm{mol} / \mathrm{kg}\end{array}$ & 8 & $\begin{array}{l}3 \cdot 790^{*}(53 \%) \\
\pm 1.050\end{array}$ & $\begin{array}{l}33 \cdot 88^{*}(49 \%) \\
\pm 6 \cdot 12\end{array}$ \\
\hline $6 \mu \mathrm{mol} / \mathrm{kg}$ & 4 & $\begin{array}{l}0 \cdot 820^{*}(90 \%) \\
\pm 0 \cdot 214\end{array}$ & $\begin{array}{l}12 \cdot 34^{*}(78 \%) \\
\pm 3 \cdot 22\end{array}$ \\
\hline
\end{tabular}

* Significant $(\mathrm{p}<0.05)$ decrease below the control value. Numbers in brackets show \% inhibition as compared with control values. 
Table 2 Effects of omeprazole given intragastrically in dose of 2 or $6 \mu \mathrm{mol} / \mathrm{kg}$ on plasma concentrations of pancreatic polypeptide in response to modified sham feeding in duodenal ulcer patients

\begin{tabular}{|c|c|c|c|c|c|c|c|}
\hline \multirow[b]{2}{*}{ Treatment } & \multicolumn{7}{|c|}{$\begin{array}{l}\text { Pancreatic polypeptide (pmolll) } \\
\text { Time (min) }\end{array}$} \\
\hline & -60 & -15 & 0 & $+15^{*}$ & +30 & +60 & +90 \\
\hline $\begin{array}{l}\text { Control } \\
\text { (placebo) }\end{array}$ & $\begin{array}{l}21 \cdot 1 \\
\pm 3 \cdot 6\end{array}$ & $\begin{array}{l}20 \cdot 4 \\
\pm 3 \cdot 7\end{array}$ & $\begin{array}{l}21 \cdot 6 \\
\pm 4 \cdot 9\end{array}$ & $\begin{array}{l}32 \cdot 7+ \\
\pm 5 \cdot 3\end{array}$ & $\begin{array}{l}29 \cdot 4 \dagger \\
\pm 2 \cdot 8\end{array}$ & $\begin{array}{l}24 \cdot 7 \\
\pm 3 \cdot 1\end{array}$ & $\begin{array}{l}22 \cdot 3 \\
\pm 4 \cdot 5\end{array}$ \\
\hline $\begin{array}{l}\text { Omeprazole } \\
\qquad \begin{array}{l}(2 \mu \mathrm{mol} / \mathrm{kg}) \\
(6 \mu \mathrm{mol} / \mathrm{kg})\end{array}\end{array}$ & $\begin{array}{l}19 \cdot 6 \\
\pm 3 \cdot 2 \\
20 \cdot 4 \\
\pm 3 \cdot 7\end{array}$ & $\begin{array}{l}20 \cdot 3 \\
\pm 2 \cdot 7 \\
21 \cdot 2 \\
\pm 3 \cdot 7\end{array}$ & $\begin{array}{l}20 \cdot 0 \\
\pm 3 \cdot 7 \\
19 \cdot 4 \\
\pm 3 \cdot 3\end{array}$ & $\begin{array}{l}29 \cdot 8+ \\
\pm 4 \cdot 2 \\
33 \cdot 4 \dagger \\
\pm 4.9\end{array}$ & $\begin{array}{l}28 \cdot 8 \dagger \\
\pm 3 \cdot 1 \\
29 \cdot 3+ \\
\pm 5 \cdot 1\end{array}$ & $\begin{array}{l}22 \cdot 6 \\
\pm 3 \cdot 7 \\
24 \cdot 6 \\
\pm 5 \cdot 1\end{array}$ & $\begin{array}{l}20 \cdot 8 \\
\pm 3 \cdot 9 \\
22 \cdot 8 \\
\pm 4 \cdot 3\end{array}$ \\
\hline
\end{tabular}

* Period when modified sham feeding was performed.

† Significantly different from basal.

Our results in duodenal ulcer patients agree with previous findings obtained in healthy volunteers showing that a benzimidazole derivative (H149/94) reduced dose dependent gastric acid response to pentagastrin after its intraduodenal administration. ${ }^{6}$ In the studies of Olbe $e t a l,{ }^{6}$ the inhibition of acid secretion by about $50 \%$ was obtained with a dose of $100 \mathrm{mg}$ of $\mathrm{H} 149 / 94$, while in our study stronger inhibition was seen at much lower dose of omeprazole. This difference could be due to the difference in the type of benzimidazole derivative used, the technique of drug administration, and the method of gastric stimulation. In our study, the drug was given intragastrically before the start of the secretory stimulation, whereas in Olbe's tests it was administered intraduondenally during stimulation with pentagastrin. The treatment with omeprazole on the resting stomach before gastric stimulation, as in our study, could cause a stronger inhibition of acid secretion than that achieved by the drug given intraduodenally when the secretory processes were fully activated, as in the study reported by Olbe $e t$ al. ${ }^{6}$ It is also possible that the inhibitory action of the agent given intragastrically, as in our study, could be attributed, at least in part, to it local action directly on the oxyntic glands. The evidence for such local action was obtained in dogs showing that after topical application of the drug to the mucosa of the fundic (Heidenhain) pouch there was relatively much stronger inhibition of histamine induced acid secretion from the pouch itself rather than from the gastric remnant. ${ }^{11}$

The major finding of our report is to show that omeprazole is a highly effective inhibitor of gastric acid secretion induced by modified sham feeding which presumably acts by vagal stimulation of the oxyntic glands. Such a stimulation in man is known to depend mainly upon the cholinergic transmission by acetylcholine released from the postganglionic cholinergic fibres both at the oxyntic cells and the G-cells. ${ }^{12}$ As the increase in serum gastrin after modified sham feeding seen in this and previous studies was negligible, ${ }^{81314}$ the role of vagal release of gastrin in the modified sham feeding-induced gastric secretion has been questioned. ${ }^{12} 13$ The major pathway of vagally induced gastric secretion appears to be direct cholinergic stimulation of the oxyntic glands. An increase in serum pancreatic polypeptide may serve as an index of vagal excitation during the modified sham feeding. ${ }^{14} 15$ Indeed, all our subjects tested showed significant rises in serum concentrations of pancreatic polypeptide in response to modified sham feeding. Our finding that omeprazole did not influence serum gastrin or pancreatic polypeptide concentrations while suppressing gastric acid secretion indicates that this drug acts selectively on the oxyntic cells without interfering with hormone release during physiological vagal excitation.

The fact that omeprazole was equally effective against modified sham feeding and pentagastrin stimulation of gastric acid secretion indicates that the drug is capable of inhibiting gastric secretion induced by various secretagogues. This agrees with animal studies showing that it is effective against stimulation by all kinds of secretagogues activating different receptor sites of the parietal cells, ${ }^{10}$ and is also confirmed by in vitro studies ${ }^{4}{ }^{6}$ on the isolated oxyntic glands showing that omeprazole counteracts the stimulation induced by histamine and db-cAMP. Thus, omeprazole seems to act on a final step in the acid secretory process within the parietal cell peripheral to the site of activation by cAMP. The inhibition by omeprazole probably involves the ATP-ase of the proton pump on the secretory canalicular surface of the parietal cells. ${ }^{1-3}$

Inhibition of modified sham feeding or pentagastrin stimulated acid secretion by omeprazole resulted from a decrease in both the volume of secretion and the acid concentration. The reduction in pepsin secretion by this drug, however, was mainly due to the fall in the volume with no change in pepsin concentration. It appears that omeprazole has a specific action only on hydrogen ion secretion by the parietal cells without affecting the secretory activity of the peptic cells.

As omeprazole is highly effective inhibitor of gastric secretion in duodenal ulcer patients, it is reasonable to assume that it may also have a favourable influence on the course of peptic ulcerations in duodenal ulcer disease and ZollingerEllison syndrome. 


\section{References}

1 Fellenius E, Berglindh T, Brändström A et al. The inhibitory action of substituted benzimidazoles on isolated oxyntic glands and $\mathrm{H}^{+} / \mathrm{K}^{+}$-ATPase. In: Schultz I, Sachs G, Forte J, Ullrich KJ, eds. Hydrogen ion transport in epithelia. Amsterdam: Elsevier, 1980: 193-202.

2 Olbe L, Berglindh T, Elander B et al. Properties of a new class of gastric inhibitors. Scand J Gastroenterol 1979; 55: suppl: 131-3.

3 Fellenius E, Berglindh T, Sachs G et al. Substituted benzimidazoles inhibit gastric secretion by blocking $\mathrm{H}^{+}+\mathrm{K}^{+}$-ATPase. Nature 1981; 290: 159-61.

4 Sjöstrand SE, Ryberg B, Olbe L. Stimulation and inhibition of acid secretion in the isolated guinea pig gastric mucosa. Acta Physiol Scand 1978; (special suppl) 181-5.

5 Fellenius E, Elander B, Wallmark B et al. Studies on acid secretory mechanisms and drug action in isolated gastric glands from man. In: Rosselin G, Fromageot P, Bonfils S, eds. Hormone receptors in digestion and nutrition. Amsterdam: Elsevier, 1979: 355-60.

6 . Olbe L, Haghlund $\mathrm{U}$, Leth $\mathrm{R}$ et al. Effects of substituted benzimidazole (H 149/94) on gastric acid secretion in humans. Gastroenterology 1982; 83: 193-8.

7 Konturek SJ, Biernat J, Kwiecień N, Oleksy J. Effect of glucagon on meal-induced gastric secretion in man.
Gastroenterology 1975; 68: 448-54.

8 Konturek SJ, Swierczek J, Kwiecień N et al. Gastric secretory and plasma hormonal responses to shamfeeding of varying duration in patients with duodenal ulcer. Gut 1981; 22: 1003-10.

9 Anson ML. The estimation of pepsin, trypsin, papain and cathepsin with hemoglobin. J Gen Physiol 1938; 22: 78-9.

10 Siegel S. Non-parametric statistics for the behavioral sciences. New York: McGraw-Hill, 1956.

11 Konturek SJ, Cieszkowski M, Kwiecień N et al. Effects of substituted benzimidazole on gastrointestinal secretions, serum gastrin and gastric mucosal blood flow in dogs. Gastroenterology 1983. (In press.).

12 Konturek SJ. Cholinergic control of gastric acid secretion in man. Scan J Gastroenterol 1981; 17: (suppl 72) $1-4$.

13 Stenquist B, Nilsson G, Rehfeld JF, Olbe L. Plasma gastrin concentrations following sham-feeding in duodenal ulcer patients. Scand J Gastroenterol 1979; 14: 305-11.

14 Konturek SJ, Kwiecień N, Obtułowicz W et al. Cephalic phase of gastric secretion in healthy subjects and duodenal ulcer patients: role of vagal innervation. Gut 1978; 20: 875-81.

15 Schwartz TW, Stenquist B, Olbe L. Cephalic phase of pancreatic polypeptide secretion studied by shamfeeding in man. Scand J Gastroenterol 1979; 14: 313-20. 